\title{
PENGEMBANGAN SISTEM INFORMASI LAYANAN PPDB PADA YAYASAN SABILILLAH SAMPANG MADURA
}

\author{
Yudha Dwi Putra Negara'), Sri Herawati ${ }^{2)}$, Faisol Arif Efendi ${ }^{3)}$ \\ ${ }^{1,2,3}$ Prodi Sistem Informasi, Fakultas Teknik,Universitas Trunojoyo Madura \\ Jl. Raya Telang, PO BOX 2 Kamal, Bangkalan \\ E-mail : 'yudha.putra@trunojoyo.ac.id
}

\begin{abstract}
ABSTRAK
Untuk meningkatkan peran Pendidikan dalam sekolah diperlukan layanan yang mendukung dalam mewujudkan Pendidikan sekolah yang dapat membangun karakter bangsa. Penerimaan perserta didik Baru merupakan salah satu layanan Pendidikan. Pelaksanaan PPDB tahun 2021 tentu berbeda dari tahun-tahun sebelumnya. Pelaksanaan PPDB tahun sebelumnya masih manual dan dilakukan secara madiri setiap sekolahan. Hal tersebut menjadi permasalahan ketika mengelolah data pendaftaran seluruh sekolah secara terpusat akan menjadi sulit sehingga mengakibatkan keterlambatan hasil pengumuman dan pelaksanaan proses belajaran mengajar karena pengelolahan yang lambat. Pihak yayasan berharap meningkatkan pelayanan pendataran peserta didik Baru dengan mengintregrasikan seluruh pendaftaran secara terpusat. Oleh karena itu penelti bermaksud meningkatkan layanan pendidikan sekolah untuk pelayanan pendaftaran perserta didik baru secara daring dengan mengembangkan Sistem Informasi Pendaftaran Peserta Didik Baru untuk meningkatkan layanan pendidikan pada Yayasan Sabilillah Sampang untuk Sekolah RA, MI, SMP, dan SMA sehingga dapat meningkatkan layanan pendidikan pada sekolah tersebut. Model perancangan dan pembangunan pengembangan perangkat perangkat lunak dengan konsep waterfall, yang secara umum memiliki tahapan: identifikasi kebutuhan sistem, study literature, pengumpulan data, analisa dan desain sistem, implementasi sistem, pengujian sistem dan target luaran. Selain itu peneliti akan melakukan evaluasi dan monitoring sistem informasi yang digunakan. Penelitian ini menghasilkan 10 kebutuhan fungsional dan desain dan perancangan menggunakan notasi diagram Unified Modelling Language (UML), dan menghasilkan sebuah sistem yang akan di uji. Pengujian black box menghasilkan hasil implementasi sistem $100 \%$ valid. Pengujian User Acceptance Test (UAT) mendapatkan hasil 100\% sistem dapat diterima dan digunakan oleh pengguna.
\end{abstract}

Kata kunci : Layanan Pendidikan, PPDB, waterfall, sabilillah.

\section{ABSTRACT}

To increase the role of education in schools, support services are needed in realizing school education that can build the nation's character. Acceptance of new students is one of the educational services. The implementation of PPDB in 2021 is certainly different from previous years. The previous year's PPDB implementation was still manual and carried out independently by each school. This becomes a problem when managing registration data for all schools centrally will be difficult, resulting in delays in the results of the announcement and implementation of the teaching and learning process due to slow management. The Foundation hopes to improve registration services for new students by integrating all registrations centrally. Therefore the Researcher intends to improve school education services for online registration services for new students by developing a New Student Registration Information System to improve education services at the Sabilillah Sampang Foundation for RA, MI, SMP, and SMA schools so as to improve education services in schools. the. The design and development model of software development with the waterfall concept, which generally has stages: identification of system requirements, literature study, data collection, system analysis and design, system implementation, system testing and output targets. In addition, researchers will evaluate and monitor the information system used. This research produces 10 functional requirements and designs and designs using Unified Modeling Language (UML) diagram notation, and produces a system that will be tested. Black Box testing resulted in $100 \%$ valid system implementation results. Testing the User Acceptance Test (UAT) gets 100\% results that the system can be accepted and used by users.

Keywords: Education Service, PPDB, waterfall, sabilillah. 


\section{PENDAHULUAN}

Pendidikan memiliki peranan penting sebagai modal utama membengun kararkter bangsa. Membentuk sumber daya manusia yang berkarakter menjadi peran penting untuk mewujudkan Indonesia baru, yaitu Indonesia yang dapat menghadapi tantangan regional dan global. Untuk meningkatkan peran Pendidikan dalam sekolah diperlukan layanan yang mendukung dalam mewujudkan Pendidikan sekolah yang dapat membangun karakter bangsa [1].

Salah satu layanan pendidikan yang disediakan oleh sekolah adalah Penerimaan perserta didik baru yang bertujuan untuk : (1) Untuk meningkatan kualitas layanan pendidikan (2) digunakan sebagai acuan bagi kepala sekolah dalam melaksanakan PPDB berdasarkan Peraturan Menteri Pendidikan dan Kebudayaan Nomor 44 Tahun 2019 Bab I Pasal 3 tentang penerimaan peserta didik baru sekolah [2].

Secara sistematis dalam pelaksanaan PPDB memiliki langkahlangkah sebagai berikut: (a) kepala sekolah mengeluarkan SK untuk membentuk panitia penerimaan peserta didik baru (Surat Keputusan) pembentukan panitia PPDB, (b) melakukan pendaftaran calon peserta didik baru dengan memberikan pengumuman dan sosialisasi terkait tentang informasi PPDB secara detail (c) menyaring atau menyeleksi calon peserta melalui dua tahap yaitu melakukan seleksi administrative terhadap peserta didik dan tahap melakukan ujian masuk kepada peserta, akan tetapi pelaksanaan ujian masuk bagi sekolah tidak diadakan karena jumlah peminatnya kurang; (d) pengumuman hasil penerimaan calon peserta didik; dan (e) mencatat data peserta didik Baru Baru dalam buku klapper dan buku induk[3].

Pembagian kuota PPDB 2020 dilaksanakan melalui 4 jalur [4] jalur perpindahan tugas orang tua/wali $5 \%$ dari jumlah peserta didik yang diterima, jalur prestasi $30 \%$ dari jumlah peserta didik yang diterima, yaitu jalur zonasi $50 \%$ dari jumlah peserta didik yang diterima, dan jumlah afirmasi $15 \%$ dari jumlah peserta didik yang diterima. Namun, jalur prestasi tidak berlaku untuk Kelas I (satu) sekolah dasar (SD) dan taman kanak-kanak (TK).

PPDB tahun 2021 dilaksanakan secara berbeda dengan tahun-tahun sebelumnya. PPDB biasanya diterapkan dengan cara orang tua dan calon peserta didik pergi dan datang langsung ke sekolah. Namun disaat wabah Covid-19 masih berlangsung, akan dirasa membahayakan karena dapat membuat kerumunan banyak orang di lingkungan sekolah yang akan bias menimbulkan menjadi klaster Baru penyebaran Covid19 yakni orang tua/wali dan peserta didik. Oleh karena itu, Kemendikbud mewajibkan untuk kegiatan PPDB dilakukan secara daring. Akan tetapi apabila tidak bisa dilakukan secara daring maka bisa dilakukan secara offline atau dengan datang langsung tetapi dengan tetap mengikuti protokol kesehatan.

Yayasan Sabilillah Sampang merupakan Lembaga Pendidikan yang memiliki beberapa sekolah diantaranya RA, MI, SMP, dan SMA. Saat ini PPDB masih dilakukan secara mandiri setiap sekolah. Hal tersebut menjadi permasalahan ketika mengelolah data pendaftaran seluruh sekolah secara terpusat akan menjadi sulit sehingga mengakibatkan keterlambatan hasil pengumuman dan pelaksanaan proses belajaran mengajar karena pengelolahan yang lambat. Pihak Yayasan berharap meningkatkan pelayanan pendataran peserta didik Baru dengan mengintregrasikan seluruh pendaftaran secara terpusat.

Permasalahan yang terjadi pada Yayasan Sabilillah Sampang adalah di Lembaga Pendidikan masih belum dikatakan maju. Yayasan Sabilillah Sampang memberikan layanan kepada siswanya dilakukan secara manual. Teknologi yang dimanfaatkan di sekolah juga tidak berpengaruh banyak. Hal ini diakibatkan karena bandwith masih sangat minim, operator atau admin belum berpengalaman dan tidak memiliki wadah sistem yang jelas. 
Penelitian Sebelumnya dengan merancang sistem informasi Penerimaan Peserta Didik Baru SDIT Al-Manar Pekanbaru. Penelitan ini menggunakan metode waterfall dalam melakukan rancang bangun sistem informasi penerimaan pesrta didik baru, metode watefall adalah suatu metode yang merupakan perancangan System Development Life Cycle (SDLC) [5].

Penelitian Sebelumnya juga merancang sebuah sistem informasi pendaftaran peserta didik baru yang berguna untuk memudahkan calon peserta didik baru beserta pihak sekolah MDTA Tauhidullah dalam melakukan pendaftaran peserta didik baru, memperoleh informasi terkini, manajemen pendaftaran peserta didik baru, manajemen penerimaan peserta didik baru, manajemen pembayaran peserta didik baru, serta manajemen laporan. Berdasarkan rancangan sistem, dibuatlah sebuah sistem informasi penerimaan peserta didik baru berbasis web [6] yang menggunakan MariaDB sebagai basis data dan PHP sebagai bahasa pemrograman[7] pada sisi backend dengan bantuan framework Laravel 7. Untuk front-end menggunakan HTML5 dan CSS3 dibantu dengan framework Bootstrap 4 [8].

Berdasarkan uraian diatas maka, peneliti bermaksut meningkatkan layanan pendidikan sekolah untuk pelayanan pendaftaran perserta didik baru secara daring dengan mengembangkan Sistem Informasi Pendaftaran Peserta Didik Baru dengan menggunakan metode perancangan dan pembangunan pengembangan perangkat perangkat lunak dengan konsep waterfall [9][10] adalah metode yang memiliki tahapan identifikasi kebutuhan sistem, study literature, pengumpulan data (wawancara, observasi, dokumentasi), analisa dan desain sistem, implementasi sistem, pengujian sistem[11][12]. Penelitian ini memiliki novelty dengan menerapkan sitem PPDB pada sebuah yayasan ini merukan sebuah kebaharuan sehingga layak di kembangkan.

\section{METODE}

Metode perancangan dan pembangunan pengembangan perangkat perangkat lunak dengan konsep waterfall adalah metode penelitian yang digunakan, yang secara umum memiliki tahapan [13][14][15]: identifikasi kebutuhan sistem, study literature, pengumpulan data (wawancara, observasi, dokumentasi), analisa dan desain sistem, Implementasi sistem, pengujian sistem dan target luaran seperti gambar 1.

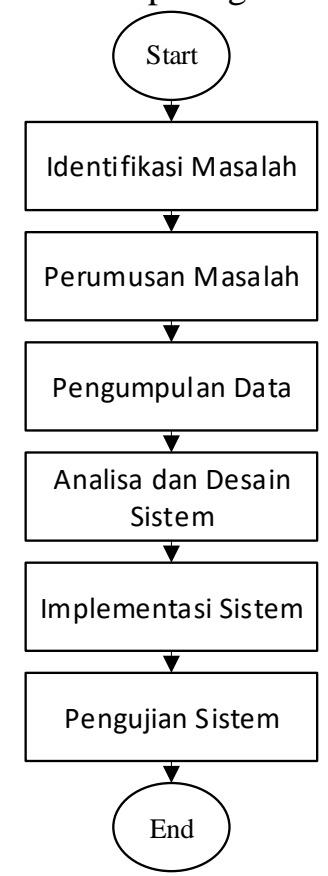

Gambar 1. Metode Penelitian

\section{HASIL DAN PEMBAHASAN}

\section{a. Analisis dan Spefisikasi Kebutuhan}

Analisis kebutuhan dilakukan dengan wawancara dan analisis hasil wawancara yang menghasilkan identifikasi aktor, dan kebutuhan fungsional. Aktor terdiri dari admin dan calon peserta didik. Kebutuhan fungsional terdiri dari 10 kebutuhan yang terbagi menjadi 5 untuk admin dan 5 untuk calon peserta didik. Hasil analisis kebutuhan fungsional admin dengan 5 Kebutuhan fungsional yaitu Sistem mampu menyediakan layanan admin untuk login, Sistem mampu menyediakan layanan admin melihat data pendaftaran, Sistem mampu menyediakan layanan admin 
mengubah data pendaftaran, sistem mampu menyediakan layanan admin menverifikasi pendaftaran, dan sistem mampu menyediakan layanan admin mengkonfirmasi pembayaran pendaftaran berdasarkan hasil pengumpulan data seperti dijelaskan pada tabel 1 .

Tabel 1. Beberapa Kebutuhan Untuk Admin

\begin{tabular}{|c|c|c|}
\hline $\begin{array}{l}\mathrm{N} \\
\mathrm{O}\end{array}$ & Kode & Penjelasan \\
\hline 1 & $\begin{array}{l}\text { PPDB- } \\
\text { F- } \\
\text { ADM- } \\
001\end{array}$ & $\begin{array}{l}\text { Sistem mampu menyediakan } \\
\text { layanan admin untuk login }\end{array}$ \\
\hline 2 & $\begin{array}{l}\text { PPDB- } \\
\text { F- } \\
\text { ADM- } \\
002\end{array}$ & $\begin{array}{l}\text { Sistem mampu menyediakan } \\
\text { layanan admin melihat data } \\
\text { pendaftaran }\end{array}$ \\
\hline 3 & $\begin{array}{l}\text { PPDB- } \\
\text { F- } \\
\text { ADM- } \\
003\end{array}$ & $\begin{array}{l}\text { Sistem mampu menyediakan } \\
\text { layanan admin mengubah data } \\
\text { pendaftaran }\end{array}$ \\
\hline 4 & $\begin{array}{l}\text { PPDB- } \\
\text { F- } \\
\text { ADM- } \\
004\end{array}$ & $\begin{array}{l}\text { Sistem mampu menyediakan } \\
\text { layanan admin menverifikasi } \\
\text { pendaftaran }\end{array}$ \\
\hline 5 & $\begin{array}{l}\text { PPDB- } \\
\text { F- } \\
\text { ADM- } \\
005\end{array}$ & $\begin{array}{l}\text { Sistem mampu menyediakan } \\
\text { layanan admin mengkonfirmasi } \\
\text { pembayaran pendaftaran }\end{array}$ \\
\hline
\end{tabular}

Selanjutnya daftar kebutuhan fungsional untuk calon peserta didik dengan 5 Kebutuhan fungsional yaitu Sistem dapat memfasilitasi calon peserta didik mengisi form pendaftaran, Sistem dapat memfasilitasi calon peserta didik menerima konfirmasi pembayaran mealuli whatsapp, sistem dapat memfasilitasi calon peserta didik untuk mengirimkan bukti pembayaran, sistem dapat memfasilitasi calon peserta didik mengisi menerima konfirmasi pendaftaran, dan sistem dapat memfasilitasi calon peserta didik mengisi data lengkap. berdasarkan hasil pengumpulan data seperti dijelaskan pada dijelaskan Tabel 2.

Tabel 2. Kebutuhan Fungsional Untuk Calon Peserta Didik

\begin{tabular}{|c|c|c|}
\hline $\begin{array}{l}\mathrm{N} \\
\mathrm{O}\end{array}$ & Kode & Penjelasan \\
\hline 1 & $\begin{array}{l}\text { PPDB } \\
\text {-F- } \\
\text { CPD- } \\
001\end{array}$ & $\begin{array}{l}\text { Sistem dapat memfasilitasi calon } \\
\text { peserta didik mengisi form } \\
\text { pendaftaran }\end{array}$ \\
\hline
\end{tabular}

\begin{tabular}{|c|c|c|}
\hline 2 & $\begin{array}{l}\text { PPDB } \\
\text {-F- } \\
\text { CPD- } \\
002\end{array}$ & $\begin{array}{l}\text { Sistem dapat memfasilitasi calon } \\
\text { peserta didik menerima } \\
\text { konfirmasi pembayaran mealuli } \\
\text { whatsapp }\end{array}$ \\
\hline 3 & $\begin{array}{l}\text { PPDB } \\
\text {-F- } \\
\text { CPD- } \\
003\end{array}$ & $\begin{array}{l}\text { Sistem dapat memfasilitasi calon } \\
\text { peserta didik untuk mengirimkan } \\
\text { bukti pembayaran }\end{array}$ \\
\hline 4 & $\begin{array}{l}\text { PPDB } \\
\text {-F- } \\
\text { CPD- } \\
004\end{array}$ & $\begin{array}{l}\text { Sistem dapat memfasilitasi calon } \\
\text { peserta didik mengisi menerima } \\
\text { konfirmasi pendaftaran }\end{array}$ \\
\hline 5 & $\begin{array}{l}\text { PPDB } \\
\text {-F- } \\
\text { CPD- } \\
005\end{array}$ & $\begin{array}{l}\text { Sistem dapat memfasilitasi calon } \\
\text { peserta didik mengisi data } \\
\text { lengkap }\end{array}$ \\
\hline
\end{tabular}

Kebutuhan non-fungsional yang dapat diartikan sebagai kebutuhan yang tidak langsung berhubungan dengan proses fungsionalitas sistem. Kebutuhan fungsional ini bersifat opsional namun bisa mempengaruhi pengalaman dan performasi sistem informasi. Kebutuhan non-fungsional yang ada dalam sistem informasi PPDB yaitu kompabilitas. Kompabilitas merupakan kemampuan sistem dapat dijalankan dari berbagai macam browser seperti Mozilla Firefox, Google Chrome, Safari, Opera dan Microsoft Edge.

\section{b. Hasil Desain dan Perancangan}

Desain dan perancangan sistem menjelaskan hasil dari analisis kebutuhan sistem yang dimodelkan dengan notasi Unified Modelling Language (UML). Diagram yang digunakan adalah Use Case Diagram, sequence, activity, dan Data Model.

\section{c. Diagram Use Case}

Potongan Use Case Diagram untuk kebutuhan fungsional admin dengan 5 fungsional antara lain mengelola data pendaftaran, mengelola data verifikasi pendaftaran, mengelola data yang ditolak, mengelola pembayaran pendaftaran, mencetak rekap pembayaran. Sedangkan untuk peserta didik baru memiliki fungsional antara lain Input data pendaftran, upload bukti pembayaran, melihat, melihat hasil verifikasi pembayaran, melihat hasil pendaftaran, seperti yang ditunjukkan pada Gambar 2. 


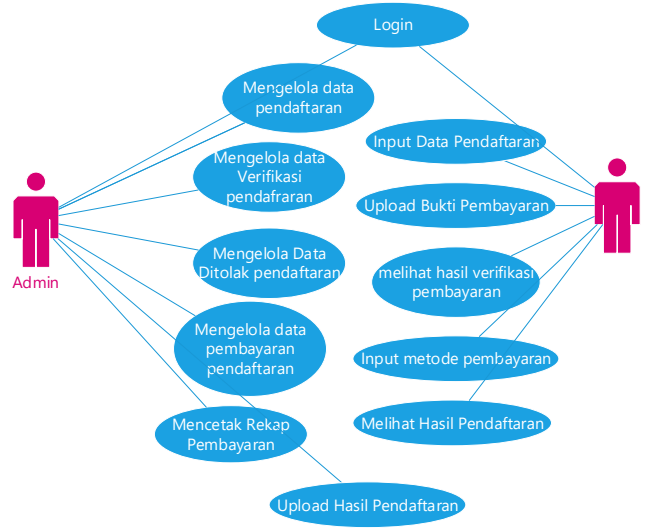

Gambar 2. Usecase Diagram

\section{d. Pemodelan Activity Diagram}

Activity diagram menggambarkan aliran dari satu aktivitas ke aktivitas yang lain yang ada dalam suatu proses pada system yang pertama adalah memasukkan alamat pendaftaran kemudian dilanjutkan sistem akan menampilkan form pendaftaran, kemudian calon peserta didik mengisi form pendaftaran, kemudian admin memverifikasi setelah itu, sistem akan mengirimkan konfirmasi pembayaran melalui whatsapp kemudian peserta didik mengirimkan bukti pembayaran melalui whatsapp kepada admin, kemudian admin mengkonfirmasi pembayaran maka sistem akan mengirim informasi login akun pada sistem, kemudian peserta didik mengisi data secara lengkap. Pada penjelasan tersebut akan dijeleskan dengan diagram aktifitas pada gambar 3 .

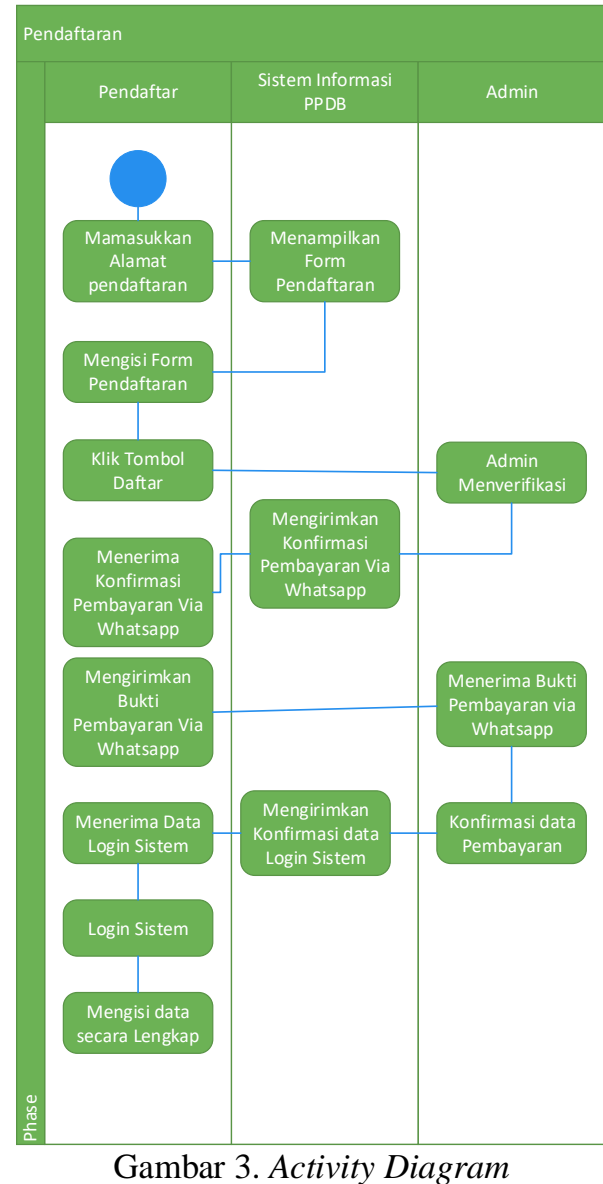

\section{e. Pemodelan Sequence Diagram}

Sequence diagram dibuat hanya pada kebutuhan fungsional yang utama dalam sistem informasi penerimaan peserta didik baru. Pendaftar melakukan pengaksesan pada form pendaftaran dan mengisi data pendaftaran kemudian pendaftar menekan tombol daftar, kemudian data dikirimkan dan disimpan dan mengirimkan konfirmasi pendaftaran melalui aplikasi whatsapp kemudian menerima konfirmasi pendaftaran melalui aplikasi whatsapp seperti dijelaskan pada gambar 4.

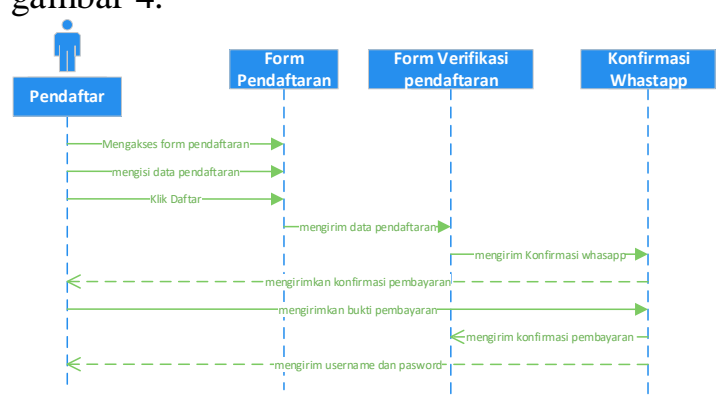

Gambar 4. Sequence Diagram 


\section{f. Perancangan Basis Data}

Perancangan basis data dilakukan berdasarkan pemetaan class dan atribut dari class diagram model. Gambar 5 merupakan potongan perancangan data model dari sistem informasi PPDB yang terdiri dari 3 entity pembayaran, pendaftaran dan user. Pendataran memiliki hubungan one to many terhadap pembayaran sedangkan pendaftaran terhadap user memiliki hubungan one to one.

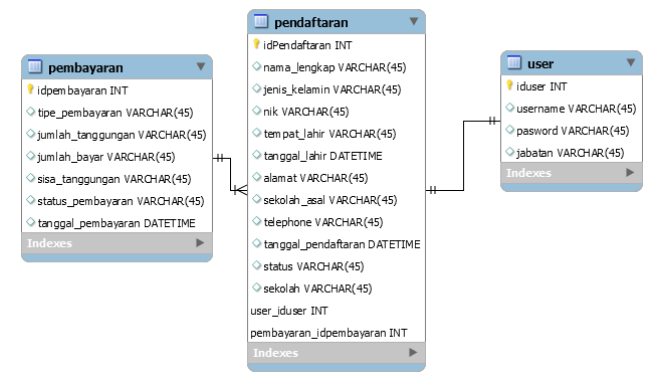

Gambar 5. Perancangan Data Model

\section{g. Perancangan Antarmuka}

Perancangan user interface Sistem Informasi PPDB yang divisualisasikan dengan wireframe. Gambar 6 merupakan wireframe halaman pendaftaran yang terdari text input nama lengkap, tempat tanggal lahir, sekolah asal, no whatsapp, no induk keluarga, jenis kelamin dan alamat. Pada halaman pendaftaran terdapat nominal biaya pendaftaran sehingga pendaftar dapat menyiapkan biayanya.

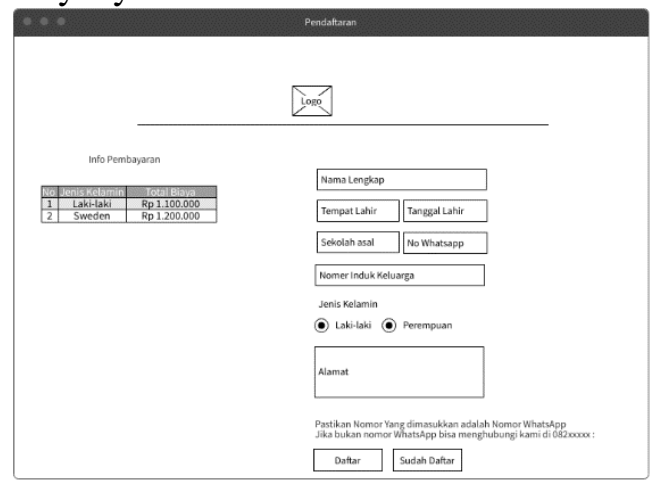

Gambar 6. Wireframe Halaman pendaftaran

\section{h. Implementasi Sistem}

Hasil dari desain dan perancangan sistem diterjemahkan dan ditulis menjadi kode program atau source code. Kode program ditulis berdasarkan fungsi-fungsi yang digunakan dalam sistem informasi
PPDB. Implementasi menggunakan bahasa PHP dan framework Laravel yang menerapkan konsep PBO dan arsitektur MVC. MVC memisahkan kode program menjadi tiga yaitu bagian model untuk akses basis data, controller untuk fungsionalitas, dan view untuk tampilan user interface.

Implementasi antarmuka menggunakan HTML sebagai markup halaman, CSS untuk styling halaman, dan Javascript.

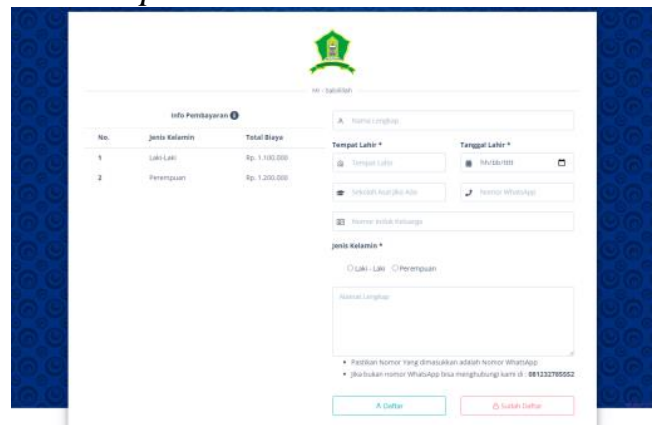

Gambar 8. Implementasi Antarmuka Halaman pendaftaran

Antarmuka ini merupakan view dalam arsitektur MVC yaitu tampilan yang dapat dilihat oleh pengguna yang merupakan halaman pendaftaran yang terdari text input nama lengkap, tempat tanggal lahir, sekolah asal, no whatsapp, no induk keluarga, jenis kelamin dan alamat. Pada halaman pendaftaran terdapat nominal biaya pendaftaran sehingga pendaftar dapat menyiapkan biayanya seperti yang ditunjukkan pada gambar 7.

\section{Pengujian Sistem}

\section{1) Pengujian Black Box}

Pengujian black box dilakukan untuk kebutuhan fungsional sistem dengan pengujian validasi. Tabel 3 merupakan pengujian black box yang menjelaskan pengujian memverifikasi data pendaftaran dengan data dan dokumen sudah ada, dan Pengujian memverifikasi data pendaftaran dengan data dan dokumen belum ada.

Tabel 3. Pengujian Black Box Memverifikasi

\begin{tabular}{llll}
\multicolumn{3}{c}{ Data Pendaftaran } \\
\hline & Hasil & \\
& Yang & & \\
& Diharapka & & Stat \\
Alur & $\mathrm{n}$ & Hasil & us \\
\hline
\end{tabular}




\begin{tabular}{|c|c|c|c|}
\hline $\begin{array}{l}\text { Pengujian } \\
\text { memverifi } \\
\text { kasi data } \\
\text { pendaftar } \\
\text { an dengan } \\
\text { data dan } \\
\text { dokumen } \\
\text { sudah } \\
\text { ada. }\end{array}$ & $\begin{array}{l}\text { Sistem } \\
\text { dapat } \\
\text { memverifi } \\
\text { kasi data } \\
\text { pendaftara } \\
\text { n dan } \\
\text { memberik } \\
\text { an pesan } \\
\text { berhasil. }\end{array}$ & $\begin{array}{l}\text { Sistem } \\
\text { memverifi } \\
\text { kasi data } \\
\text { pendaftara } \\
\text { n dan } \\
\text { menampil } \\
\text { kan pesan } \\
\text { berhasil. }\end{array}$ & $\begin{array}{l}\text { Vali } \\
\text { d }\end{array}$ \\
\hline $\begin{array}{l}\text { Pengujian } \\
\text { memverifi } \\
\text { kasi data } \\
\text { pendaftar } \\
\text { an dengan } \\
\text { data dan } \\
\text { dokumen } \\
\text { belum } \\
\text { ada. }\end{array}$ & $\begin{array}{l}\text { Sistem } \\
\text { menampil } \\
\text { kan pesan } \\
\text { "Gagal, } \\
\text { dokumen } \\
\text { belum } \\
\text { lengkap". }\end{array}$ & $\begin{array}{l}\text { Sistem } \\
\text { menampil } \\
\text { kan pesan } \\
\text { "Gagal, } \\
\text { dokumen } \\
\text { belum } \\
\text { lengkap". }\end{array}$ & $\begin{array}{l}\text { Vali } \\
\mathrm{d}\end{array}$ \\
\hline
\end{tabular}

\section{2) Pengujian UAT}

Pengujian UAT dibagi menjadi dua berdasarkan identifikasi aktor yaitu admin dan calon peserta didik. Kriteria yang digunakan untuk pengujian UAT yaitu Functional Correctness and Completeness, Usability, Data Conversain. Responden berjumlah 2 orang dengan rincian 1 orang sebagai aktor admin dan 1 orang sebagai aktor calon peserta didik.

Terdapat beberapa pernyataan yang sesuai dengan kriteria dan diujikan untuk aktor admin. Responden mengakses sistem informasi untuk mencoba fungsionalitas sistem. Tabel 5 merupakan hasil pengujian UAT untuk aktor admin dengan menghasilkan Functional correctness and completeness menghasilkan $100 \%$, usability menghasilkan 100\%, dan data conversion menghasilkan $100 \%$.

Tabel 4. Hasil Pengujian UAT Terhadap Aktor Admin

\begin{tabular}{clc}
\multicolumn{3}{c}{ Terhadap Aktor Admin } \\
\hline $\mathrm{N}$ & Kriteria & $\begin{array}{c}\text { Persent } \\
\text { asi }\end{array}$ \\
\hline & $\begin{array}{l}\text { Functional Correctness and } \\
1\end{array}$ & Completeness \\
\hline 2 & Usability & $100 \%$ \\
\hline 3 & Data Conversion & $100 \%$ \\
\hline & Terdapat pernyataan yang & $100 \%$ \\
\hline
\end{tabular}

Terdapat pernyataan yang sesuai dengan kriteria yang diujikan untuk aktor calon peserta didik. Tabel 5 merupakan hasil pengujian UAT untuk aktor calon peserta didik dengan menghasilkan functional correctness and completeness menghasilkan
$100 \%$, usability menghasilkan 100\%, dan data conversion menghasilkan $100 \%$.

Tabel 5. Hasil Pengujian UAT

\begin{tabular}{lll} 
& Terhadap Aktor Calon Peserta Didik \\
\hline $\mathrm{N}$ & Kriteria & $\begin{array}{l}\text { Persent } \\
\text { asi }\end{array}$ \\
\hline & $\begin{array}{l}\text { Functional Correctness and } \\
1\end{array}$ & $\begin{array}{ll}\text { Completeness } \\
100 \%\end{array}$ \\
\hline 2 & Usability & $100 \%$ \\
\hline 3 & Data Conversion & $100 \%$ \\
\hline
\end{tabular}

Pengujian UAT mendapatkan persentasi $100 \%$ yang dihitung dari ratarata pengujian UAT terhadap aktor admin dan calon peserta didik.

\section{3) Pengujian Kompabilitas}

Pengujian kompabilitas menggunakan aplikasi SortSite 6. Pengujian kompabilitas ini untuk menguji kemampuan sistem dalam penyesuaian dengan peramban (browser) yang berbeda-beda.

\begin{tabular}{r|c|c|c|c|c|c|c|c|c|} 
Browser & IE & Edge & Firefox & Safari & Opera & Chrome & iOS & Android \\
Version & 11 & 95 & 93 & 15 & 80 & 95 & $\leq 14$ & 15 & 95 \\
\hline Critical Issues & $\odot$ & $\odot$ & $\odot$ & $\odot$ & $\odot$ & $\odot$ & $\odot$ & $\odot$ & $\odot$ \\
Major Issues & $\odot$ & $\odot$ & $\odot$ & $\odot$ & $\odot$ & $\odot$ & $\odot$ & $\odot$ & $\odot$ \\
Minor Issues & $\odot$ & $\odot$ & $\odot$ & $\odot$ & $\odot$ & $\odot$ & & & $\odot$
\end{tabular}

Gambar 11. Hasil Pengujian Kompabilitas

\section{SIMPULAN}

Setelah semua tahap dalam penelitian dan pengembangan sistem informasi dilakukan dapat ditarik kesimpulan bahwa analisis kebutuhan menghasilkan identifikasi aktor terdapat dua jenis yaitu admin dan calon peserta didik. Terdapat 10 kebutuhan fungsional dengan rincian 5 kebutuhan untuk aktor admin dan 5 kebutuhan untuk aktor calon peserta didik. Desain dan perancangan menggunakan notasi diagram Unified Modelling Language (UML) yaitu diagram activity, sequence, dan class diagram. Pengujian dilakukan menggunakan metode black box berupa pengujian validasi dan pengujian penerimaan pengguna dengan UAT. Pengujian black box menghasilkan hasil implementasi sistem $100 \%$ valid. Pengujian UAT mendapatkan hasil $100 \%$ 
sistem dapat diterima dan digunakan oleh pengguna.

\section{SARAN}

Saran untuk penelitian selanjutnya yaitu dapat menambahkan fitur baru yang relevan seperti fitur untuk pengumuman, fitur ujian masuk daring, dan fitur tes psikologi. Serta dapat dilakukan evaluasi dan perbaikan tampilan sistem informasi Penerimaan Peserta Didik Baru.

\section{DAFTAR PUSTAKA}

[1] N. Ilma, "Peran Pendidikan Sebagai Modal Utama Membangun Karakter Bangsa," TADBIR J. Manaj. Pendidik. Islam. IAIN Sultan Amai Gorontalo, vol. 3, no. 1, pp. 82-87, 2017, [Online]. Available:

http://journal.iaingorontalo.ac.id/in dex.php/tjmpi.

[2] D. Wahyuni, "Permendikbud Nomor 44 Tahun 2019," Permendikbud, pp. 1-25, 2019.

[3] J. Yusuf, Himmah Spritual sebagai Alternatif Penegakan Disiplin dalam Program Manajemen Peserta Didik. Gre Publishing, 2020.

[4] Permendikbud, "Ifografis PPDB 2020," 2020.

[5] H. Abdi Muhaimin, "Rancang Bangun Sistem Informasi Penerimaan Peserta Didik Baru Berbasis Web Pada SDIT AlManar Kota Pekanbaru," J. Ilmu Komput., vol. 10, no. 206, pp. 8-13, 2021, doi: 10.37859/jf.v10i1.1903.

[6] L. I. Sari, "Pemanfaatan Web Sebagai Sistem Informasi PPDB pada SLBN Koba Bangka Tengah," vol. 5, no. 2, pp. 64-73, 2020.

[7] M. R. Irwanto, T. Widiyaningtyas, and M. Z. Arifin, "Implementasi algoritma monte carlo pada sistem informasi penerimaan peserta didik baru (ppdb) secara online," vol. 40, no. 1, pp. 69-78, 2017.

[8] S. Nasional, T. Elektro, S. Informasi, and T. Informatika, "Seminar Nasional Teknik Elektro, Sistem Informasi, dan Teknik
Informatika," pp. 79-84, 2021.

[9] N. Putu et al., "RANCANG BANGUN SISTEM PENERIMAAN PESERTA DIDIK BARU ( PPDB ) SECARA ONLINE PADA SMP IT," pp. 251-259.

[10] H. Apriyani et al., "PERANCANGAN PROGRAM PENERIMAAN PESERTA DIDIK BARU," vol. 3, no. 3, pp. 44-47, 2019.

[11] I. Basic, M. Understanding, R. Oktavia, and R. Ferdhiana, "The development of ppdb ( admission of new students ) application to develop the quality of new students ' recapitulation administration in vocational high school bumi cikajang application to develop the quality of new students recapitulation administration in vocational high school bumi cikajang," pp. 0-7, doi: $10.1088 / 1742-$ 6596/1280/3/032041.

[12] D. A. Dwipitaloka, E. D. Oktaviyani, and F. Sylviana, "SISTEM INFORMASI PENERIMAAN PESERTA DIDIK BARU ( PPDB ) DAN REGISTRASI ONLINE BERBASIS WEBSITE PADA SMP NEGERI 6 PALANGKA RAYA," vol. 14, no. 2, pp. 119128, 2020.

[13] m. S. Rosa AS, Rekayasa Perangkat Lunak: Terstruktur dan berorientasi objek. Informatika Bandung, 2018.

[14] P. Pn and M. Penelitian, "Activity diagram

dalamaplikasipendaftaranmahasis wabaruyaitu :," vol. 1, no. 2017, pp. 5-9, 2020.

[15] N. L. Hasanah, "RUMAH KOST BERBASIS WEB," vol. 8, no. 2, pp. $78-86,2020$. 